\title{
Circulation And TRAnsport in the Western Boundary CuRREnts at CAPE FAREWELl, GREenland
}

N.P. Holliday, S. Bacon, J. Allen, E. L. McDonagh NATIONAL OCEANOGRAPHy CENTRE, SOUTHAMPTON, UK

JOURNAL OF PHYSICAL OCEANOGRAPHY

Corresponding author address

N. Penny Holliday

National Oceanography Centre, Southampton

Waterfront Campus, European Way, Southampton, SO14 3ZH, UK

email: penny.holliday@noc.soton.ac.uk 
ABSTRACT

The circulation and volume transports in the western boundary currents around Cape Farewell, Greenland, are derived from full-depth hydrographic and velocity measurements from August-September, 2005. The western boundary currents from surface to seafloor transport $40.5 \pm 8.1 \mathrm{~Sv}$ southwards in the Irminger Sea, and $53.8 \pm 10.8$ Sv northwards in the Labrador Sea. The Deep Western Boundary Current (DWBC, defined as water with potential density greater than $27.80 \mathrm{~kg} \mathrm{~m}^{-3}$ ) transports $12.3 \pm 2.5 \mathrm{~Sv}$ southwards in the Irminger Sea. The deep water transport is reduced south of Cape Farewell, where it changes flow direction from southwards to northwards (the south corner). At a section over the Eirik Ridge, a bathymetric feature extending southwest of Cape Farewell, the DWBC transports $8.7 \pm 1.7 \mathrm{~Sv}$ westwards. The reduction in transport at the south corner is associated with decreased velocities within the deepest layers, and the volumetric loss of the most saline deep water types. The observations suggest that the part of the shallow and deep western boundary currents diverge at the south corner. Downstream in the eastern Labrador Sea the deep water transport is increased to $19.7 \pm 3.9 \mathrm{~Sv}$ northwards, with the addition of recirculating denser deep waters. The representativeness of the results from the semi-synoptic survey are discussed with reference to companion current meter measurements of the DWBC.

\section{INTRODUCTION}

The details of circulation pathways and transport in the Western Boundary Currents (WBC) of the northwest North Atlantic are an aspect of the global circulation that remain imperfectly understood. The general nature of the currents around Greenland and northeast Canada has been known for some time as follows; 
shallow components transport both freshwater from the high latitudes and salinity from the subpolar regions into the Labrador Sea. There they combine with the underlying cold, dense northern overflows to form North Atlantic Deep Water, the southward-flowing limb of the Atlantic meridional overturning circulation (Dickson and Brown, 1994, Hansen and Østerhus, 2000, Schott et al, 2004). The currents are strongly barotropic and constrained by the topography, flowing southwards along the continental slope through the western Irminger Sea, northwards through the eastern Labrador Sea, and eventually southwards along the western margin of the Labrador Sea.

Extensive measurement programmes in the western Labrador Sea region have recently yielded new information about transport pathways, volume transport and variability of the WBCs there (Fischer et al, 2004, Schott et al, 2004, Stramma et al, 2004). The deep currents to the east of Greenland have been the subject of prolonged measurement programmes giving estimates of volume transports (Dickson and Brown, 1994, Dickson et al, 2008). Recent high resolution CTD (conductivitytemperature-depth) surveys have provided new information about details of smaller shallow currents such as the East Greenland Coastal Current (Bacon et al, 2002, Sutherland and Pickart, 2008) and the East Greenland Spill Jet (Pickart et al, 2005). However, details of the western boundary currents to the south of Greenland, where they turn the corner from southward flow through the Irminger Sea to northward flow in the Labrador Sea, remain largely unresolved. This is because surveys have tended to focus on either the Irminger Sea or the Labrador Sea, and because programmes that have surveyed the region south of Greenland have mostly been bottle or CTD only, lacking in direct current observations. There are drifter tracks in the region (see for example Cuny et al, 2002) but analyses rarely examine in detail the region directly to 
the south of Cape Farewell. The well-known exception to this was a CTD section and 2-month long current meter records from 1978 reported in Clarke (1984) which provided the only reported estimates of absolute transport south of Greenland (33.5 Sv, surface-to-seafloor, flowing westwards across a section running directly south from Cape Farewell to the edge of the continental slope at $\sim 3300 \mathrm{~m}$ ). The same measurements are often reported as 13.3 Sv of Deep Western Boundary Current (DWBC, Dickson and Brown, 1994).

In schematics of circulation of the northwest Atlantic, all southward flowing WBCs in the Irminger Sea are shown rounding the corner at Cape Farewell, flowing northwards directly into the Labrador Sea (e.g. Schott et al, 2004). Some schematics show the currents keeping close to the coast of the Cape, others show them moving slightly off-shore over the bathymetric feature, the Eirik Ridge, which extends southwestwards from the Cape (e.g. Clarke, 1984). The collective impression is that all the WBCs, from the surface to the seafloor flow sharply around the Cape (the turning point which we will refer to as the south corner), directly into the mixing pot of the Labrador Sea where lateral mixing and extreme deep convection further transform the inflowing waters into North Atlantic Deep Water.

Apart from the Clarke (1984) values, there are a small number of estimates of total surface to seafloor transport in the WBC system close to the south corner. In the southern Irminger Sea, just upstream of the south corner, estimates of surface to seafloor transport of southward flowing water vary between 26 and $40 \mathrm{~Sv}$. It has been reported as $32.2 \pm 3.2 \mathrm{~Sv}$ in 1991 from geostrophic velocities referenced with ADCP (acoustic Doppler current profiler) data (Bersch, 1995), 26-27 Sv in 1991 from an inverse model constrained by ADCP data (Bacon, 1997), and as 39.0 Sv in 1997 and 
31.6 Sv in 2002 also from an inverse model constrained by ADCP data (Lherminier et al, 2007). In the eastern Labrador Sea, just downstream of the south corner, there are fewer reported transport estimates, but an inverse model using data from a number of years gave northward transports of 40-50 Sv (Reynaud et al, 1995).

In this analysis we use hydrographic data and directly measured velocity profiles to establish the circulation scheme and volume transports of the WBCs in the Cape Farewell region to the south of Greenland. The results represent a "snap-shot" of conditions as measured in August-September 2005, focussing on the circulation pathways and instantaneous transports around the south corner between the Irminger Sea and the Labrador Sea. The outline of the paper is as follows. In Section 2 we describe the data analysed and the methodology used to determine the velocities and transports. Section 2 also outlines the water mass analysis described in the literature and adapted for this study. In Section 3 we describe the results in terms of transport and mean velocities in the major currents, along with water mass modification that takes place in the deepest layers. In Section 4 we summarise the main findings of the analysis, and in Section 5 we discuss the implications of the results in the context of existing knowledge, long-term direct measurements of transports, and future analysis.

\section{DATA AND METHODS}

a. The D298 CTD/LADCP survey

In August and September 2005 RRS Discovery cruise 298 completed a CTD and ADCP survey around Cape Farewell, the southernmost part of Greenland (Bacon, 2006). The survey consisted of three sections from the coast to the deep ocean (Figure 1): in the southern Irminger Basin, along the crest of Eirik Ridge which is a bathymetric feature which extends south-westwards from Cape Farewell (Chough and 
Hess, 1985) and in the southern Labrador Sea. The Eirik Ridge section included two short CTD sections normal to the Ridge, designed to survey the DWBC. At each station a SeaBird 911 plus CTD was lowered in a frame that contained 24 x $10 \mathrm{~L}$ water sampling bottles and two lowered ADCPs (LADCPs, RDI Workhorse $300 \mathrm{kHz}$, one upward- and one downward-looking). Calibrated CTD sensor accuracies were 1 dbar (pressure), $0.001{ }^{\circ} \mathrm{C}$ (temperature) and 0.001 (salinity). Data from a shipboard RDI $150 \mathrm{kHz}$ broadband ADCP (SADCP) were used to calculate underway absolute water velocities.

\section{b. Velocities, Transports and Bottom Triangles}

In this section we describe the method for deriving absolute geostrophic velocities using CTD station pairs and ADCP data, and computing transports including the treatment of bottom triangles (the part of the water column below the deepest common level of a station pair). The density gradient between station pairs provides an estimate of geostrophic shear through the thermal wind equation. With care, ADCP profiles may be used to find a level of known velocity in order to reference the geostrophic shear (McDonagh et al, 2008). This should provide an improved measure of the mean flow over selecting a mid-depth or seafloor level of no motion.

Raw data from the LADCPs were processed using the Lamont Doherty Earth Observatory LADCP Software Version 7b Dec 2002 (Visbeck, 2002) using GPS navigation data and bottom-tracked velocities to obtain absolute on-station velocities. LADCP data quality was assessed initially during the processing, and SADCP data provided an independent check for the LADCP velocities. Throughout the cruise there was generally good agreement between the two data sources in the upper $500 \mathrm{~m}$. 
Subsequently, individual LADCP profiles were examined manually for consistency between their down-cast velocity profiles and up-cast velocity profiles (below $250 \mathrm{~m}$, since the surface layer is expected to contain currents that vary during the cast). If portions of the profile exceeding $100 \mathrm{~m}$ in depth had differences of $>0.05 \mathrm{~m} \mathrm{~s}^{-1}$ between up and down casts in the $u$ or $v$ components of velocity, the whole profile was considered suspicious and was not included in subsequent analysis. This was the case in 8 of 60 LADCP profiles. The difference between up- and down-casts velocity $\mathrm{u}$ and $\mathrm{v}$ components $(\delta u, \delta v)$ calculated at all depths for all (non-suspicious) stations, and averaged over the whole cruise were as follows; $\overline{\delta u}=-0.003 \pm 0.015 \mathrm{~m} \mathrm{~s}^{-1}, \overline{\delta v}=-$ $0.002 \pm 0.013 \mathrm{~m} \mathrm{~s}^{-1}$. In the case of the acceptable LADCP profiles, data deeper than $250 \mathrm{~m}$ were used to compute the reference velocity, to avoid contamination by surface transient currents. For the 8 stations with suspect LADCP data, the on-station SADCP provided absolute velocities in the depth range $250-500 \mathrm{~m}$. At 3 stations in water depth of $<100 \mathrm{~m}$ where LADCP data were not available, the SADCP provided absolute velocities. At two stations over the Eirik Ridge the LADCP recorded high wave-number variability away from the seafloor, which were difficult to reconcile with the relatively smooth geostrophic profile. In those cases the deepest $300 \mathrm{~m}$ of the LADCP, including the bottom tracked data, provided the reference velocities.

The ADCP data were de-tided using predictions obtained from the Oregon State University TOPEX/Poseidon Global Inverse Solution 1/4 (Egbert et al., 1994, Egbert and Erofeeva, 2002). There were 3 cases of unusually high predictions of tidal currents in the shallowest water near the coast (less than $200 \mathrm{~m}$ ); those were rejected as probably in error and the deepest ADCP-derived velocities were taken to represent the barotropic tides (c.f. Bacon et al, 2002). 
Next a mean de-tided velocity profile was calculated for each station pair, and the cross-track component obtained. The difference between the calculated geostrophic shear and the cross-track ADCP velocity profile was derived over the depth ranges described above. The mean difference was taken to be the correction and added to the geostrophic shear to obtain absolute velocity and volume transport between each station pair.

The method chosen to fill bottom triangles was to assume constant velocity from the deepest common level to the seafloor, and use linearly-interpolated bottom topography. The survey station spacing leads to bottom triangles with height above seafloor $(h)$ typically of $200-300 \mathrm{~m}$. To examine the uncertainty associated with this method, we examined the differences between the measured LADCP velocity at $h=$ $200 \mathrm{~m}$ and a profile with velocity adjusted to be constant from $200 \mathrm{~m}$ to the seafloor. Across the nine DWBC stations in the Irminger Sea section, the mean of the differences is $-0.0083 \mathrm{~ms}^{-1}$, standard deviation $0.0268 \mathrm{~ms}^{-1}$. From this we conclude the constant velocity method is reasonable, and have applied it to all of the station pairs. The calculation of transport within the bottom triangles provides $3.7 \mathrm{~Sv}$ of the total DWBC $\left(>27.80 \mathrm{~kg} \mathrm{~m}^{-3}\right)$ transport of $12.3 \mathrm{~Sv}$ (southwards) across the Irminger Sea section.

\section{c. Error estimates}

The error estimates we provide are based on two sources of experimental errors in the dataset; the instrumental error from the ADCPs (estimated to be \pm 0.02 $\mathrm{ms}^{-1}$ from the comparison of up- and downcasts) and the bottom triangle method error (estimated to be $\pm 0.03 \mathrm{~ms}^{-1}$ ). In the $\mathrm{WBC}$, core velocities range from 0.10 to 0.30 $\mathrm{ms}^{-1}$, suggesting the experimental errors could be $10-30 \%$ of the estimated velocities, 
with smallest errors in the fast-flowing DWBC. We therefore provide error estimates at $20 \%$ of the total transport values. The representativeness of the observations of the mean flow is examined in the Discussion section by comparison with current meter measurements.

\section{d. Water Mass Analysis}

WBCs are typically defined in terms of their velocity structure and by the water masses that they carry. It is usual practice to identify density ranges for individual water masses associated with particular parts of the WBC system. Here we briefly review the literature about water masses around Cape Farewell and describe how that information is used in this analysis. The D298 CTD data are shown in Figures 2, 3 and 4, with selected isopycnals highlighted to show the density ranges of individual water masses. Some mixing lines are also highlighted in Figure 4 and discussed in the Results section.

The shallow, intermediate and deep water masses in this region are reasonably well understood. The shallow layers (less than $1000 \mathrm{dbar}$ ) contain cold fresh waters derived from the Arctic and enhanced en route by glacier and sea-ice melt, as well as warm saline Atlantic water derived from the eastern Irminger Sea. The freshest water masses are carried southward through the Irminger Sea on the shelf in the East Greenland Coastal Current (EGCC) and the East Greenland Current (EGC) (Bacon et al, 2002, Sutherland and Pickart, 2008). As the EGCC and EGC turn the corner into the Labrador Sea they merge (Holliday et al, 2007) and become known as the West Greenland Current which circulates around the margins of the Labrador Sea (Clarke, 1984). Some portion of the West Greenland Current flows northward into Baffin Bay (Cuny et al, 2002; Bacon et al, 2008). At the continental shelf break of the west 
Irminger Sea, the EGC includes a warm saline core of Atlantic-origin water (sometimes called the Irminger Current) which also flows into the Labrador Sea where it is known as Irminger Water. Following Holliday et al (2007), $\sigma_{\theta}=27.70 \mathrm{~kg}$ $\mathrm{m}^{-3}$ is chosen as the deep density limit for the combined shallow currents (EGC, EGCC and recirculating Sub Arctic Surface Water (SASW, Figures 2 and 3). Transports in the EGC and EGCC have been fully described in Holliday et al (2007), in which they are distinguished from the SASW. Here all water lighter than $\sigma_{\theta}=$ $27.70 \mathrm{~kg} \mathrm{~m}^{-3}$ is shown together and only briefly discussed.

The dominant intermediate water mass is the Labrador Sea Water (LSW), identifiable by characteristic low salinity (Figures 2 and 3) and low potential vorticity and typically filling the depth range of 500 to $2000 \mathrm{~m}$ (Clarke and Gascard, 1983, Yashayaev et al, 2007a). A smaller but notable influence at intermediate depths is the relatively saline Icelandic Slope Water (van Aken and de Boer, 1995) which can be seen as a salinity maximum at around $1000 \mathrm{~m}$ between the two salinity minima of LSW (Figure 4, see also Yashayaev et al, 2007b). For this analysis of surface to seafloor transports at Cape Farewell in August-September 2005, we define the intermediate layer (including Labrador Sea Water and Icelandic Slope Water) as being in the range $\sigma_{\theta}=27.70-27.80 \mathrm{~kg} \mathrm{~m}^{-3}$ (Figure 4). The use of $\sigma_{\theta}=27.80 \mathrm{~kg} \mathrm{~m}^{-3}$ as an indicator of the DWBC includes some recirculating LSW (as discussed by Dickson and Brown (1994)) but has been adopted by the majority of authors and is used here. For a detailed study of intermediate water it can be misleading to define all North Atlantic LSW by a single density range, since the density varies from year to year in the formation region, and subsequently changes through mixing with surrounding waters as it flows into the rest of the North Atlantic (Yashayaev et al, 2007b). 
The water masses in the DWBC originate in the dense northern overflows; the cold Denmark Strait Overflow Water (DSOW) which has descended from the Denmark Strait sill at the northern end of the Irminger Sea, and the North East Atlantic Deep Water (NEADW), also called Gibbs Fracture Zone Water (GFZW), (McCartney, 1992, Saunders, 1994, Keike and Rhein, 2006) containing mixed and modified Iceland-Scotland Overflow Water (ISOW) with some influence from Antarctic-origin bottom waters. The boundary between the two densest water masses is turbulent and an active mixing zone (Lauderdale et al, 2008). Typically the deepest water masses are defined as those denser than $\sigma_{\theta}=27.80 \mathrm{~kg} \mathrm{~m}^{-3}$ (e.g. Dickson and Brown, 1994, Keike and Rhein, 2006, Lherminier et al, 2007) or colder than $3^{\circ} \mathrm{C}$ (Saunders, 2001). The boundary between the DSOW and the NEADW is less consistent between authors; $\sigma_{\theta}=27.85 \mathrm{~kg} \mathrm{~m}^{-3}$ (Dickson et al, 2008, Bacon and Saunders, submitted to JPO), $\sigma_{\theta}=27.88 \mathrm{~kg} \mathrm{~m}^{-3}$ (Dickson and Brown, 1994, Stramma et al, 2004, Keike and Rhein, 2006), or $<2{ }^{\circ} \mathrm{C}$ (Saunders, 2001). Here we define NEADW as lying in the potential density range $\sigma_{\theta}=27.80-27.88 \mathrm{~kg} \mathrm{~m}^{-3}$, and DSOW as having $\sigma_{\theta}>27.88 \mathrm{~kg} \mathrm{~m}^{-3}$ (Figure 4).

The CTD sections run from the continental shelf into the middle of the deep ocean basin in order to measure the WBC. In the following analysis we distinguish between the WBC which is entirely captured by the survey, and any components recirculating in the opposing direction which are often not fully sampled.

\section{RESULTS: TRANSPORTS AND PATHWAYS}

The transport calculations are summarised in Table 1 and Figures 5, 6 and 7, where individual components of the WBC system are distinguished from one another. In this section we describe those results and evidence from water mass analysis to 
derive a circulation and transport scheme between the sections. In the following text, figures and tables, positive values indicate northward flow, while negative values indicate southward flow (velocity and transport).

a. Surface to seafloor transport in the boundary current system.

We first describe the volume transports from the surface to the seafloor within the boundary current system. The Irminger Sea and Labrador Sea panels in Figure 5 show that rather than a series of individual currents distinguishable by their property or velocity profiles (the traditional division into shallow EGC, recirculating intermediate water and DWBC), there is unidirectional surface to seafloor flow between the stations in-shore of the $3300 \mathrm{~m}$ isobath. This characteristic allows us to define the WBC by the velocity field rather than location, ie. all southward flow adjacent to the coast across the Irminger Sea section, all westward flow adjacent to the coast across the Eirik Ridge section, and all northward flow adjacent to the coast across the Labrador Sea section. In Figure 6a, all station pairs in-shore of the dotted line were observed to have net flow from the Irminger Basin around the south corner and into the Labrador Sea. Figure 5 shows that here are high velocities at all depths from the surface to the seafloor, with enhanced shear in the upper ocean against the continental slope, and enhanced shear in the densest water close to the seafloor. Intermediate waters have high transport associated with them too. The D298 2005 survey gives a top to bottom WBC transport estimate of $-40.5 \pm 8.1 \mathrm{~Sv}$ in the Irminger Sea, similar to the Lherminier et al (2007) inverse estimates of $-39.0 \pm 1.0 \mathrm{~Sv}$ in 1997 and $-31.6 \pm 1.3 \mathrm{~Sv}$ in 2002. Lherminier et al (2007) noted that the decline in transport from 1997 to 2002 was consistent with the decreasing circulation of the subpolar gyre described by Hakkinen and Rhines (2004). With the large uncertainty associated with 
these new results it is difficult to say whether the apparent increase of the WBC transport in 2005 is indicative of increased subpolar gyre circulation.

Figure 6a shows that, as expected, the net direction of transport from the surface to seafloor adjacent to southern Greenland is southward through the Irminger Sea and northward into the Labrador Sea. However it is notable that across the Eirik Ridge section the transport is reduced to $29.6 \pm 5.9 \mathrm{~Sv}$, a decrease of about $25 \%$, while at the Labrador Sea section the transport is nearly doubled to $53.8 \pm 10.8 \mathrm{~Sv}$, similar to the Reynaud et al (1995) estimate of 40-50 Sv. The western part of the Eirik Ridge section measured 43.4 \pm 8.7 Sv flowing south-eastwards, though this is not fully resolved. In the following subsections we will show that when individual water masses or density classes are examined, the WBC is revealed to be much less continuous than this figure suggests, with the main current being depleted as flow diverges in the vicinity of the Eirik Ridge section, and being supplemented with the addition of recirculating elements in the Labrador Sea. The part of the section measuring the WBC in each density class is defined as those station pairs observed to have transport consistent with the general flow of the WBC from the Irminger Sea to the Labrador Sea. This definition leads to a different set of station-pairs for each density class, but provides comparative transport estimates between each section.

\section{b. Deep Western Boundary Current}

The transport observed in the DWBC $\left(\sigma_{\theta}>27.80 \mathrm{~kg} \mathrm{~m}^{-3}\right)$ during the D298 August/September 2005 survey is as follows; $-12.3 \pm 2.5 \mathrm{~Sv}$ across the Irminger Sea section, $8.7 \pm 1.7 \mathrm{~Sv}$ across the Eirik Ridge section and $19.7 \pm 3.9 \mathrm{~Sv}$ across the Labrador Sea section (Figure 6). Within the DWBC, $60-80 \%$ of the transport is in the shallower NEADW; $-8.7 \pm 1.7 \mathrm{~Sv}$ across the Irminger Sea section, $7.4 \pm 1.5 \mathrm{~Sv}$ 
across the Eirik Ridge section and 12.0 $\pm 2.4 \mathrm{~Sv}$ across the Labrador Sea section (Table 1 and Figure 6).

The baroclinic component of the transport can be estimated using the same methodology employed by Bacon (1998) and Keike and Rhein (2006). Both analyses obtained estimates of baroclinic transports by referencing the geostrophic shear to a level of no motion at intermediate depths where the vertical shear was low (1000 dbar and 1400 dbar respectively). In Figure 7 the vertical structure of the WBC is illustrated by subdividing the transport into pressure and density bins. Ignoring for the moment the vertically inclined boundary of the WBC, in Figures $7 \mathrm{a}, 7 \mathrm{~b}$ and $7 \mathrm{~d}$ we have chosen stations within the WBC (stations 9-23 on the Irminger Sea section, stations 24-32 on the Eirik Ridge section, and stations 38-48 on the Labrador Sea section). At all those station pairs the vertically integrated transport was consistent with the net WBC flow from the Irminger Sea to the Labrador Sea (Figure 6). The Eirik Ridge stations to the southwest of the WBC, across which flow opposes the WBC, are shown in Figure 7c.

Figure 7 shows that there is no mid-depth level of no motion within the WBC, indicating a large contribution from barotropic flow. Table 2 gives the baroclinic transport of the DWBC at the Irminger Sea and Labrador Sea sections using the two mid-depth levels of no motion used by Bacon (1998) and Keike and Rhein (2006). It can be seen that the baroclinic transport accounts for approximately half of the total transport at the Irminger Sea and Labrador Sea sections. A comparison with the Bacon (1998) and Kieke and Rhein (2006) time series of DWBC baroclinic transports in the Irminger Sea and Labrador Sea shows the 2005 survey data to be slightly higher than the long-term average (1950s to 1990s). 
The transport estimates within this survey raise two notable points; firstly that the DWBC decreases in transport as it flows around the south corner at Cape Farewell, and secondly that the DWBC subsequently increases in transport within the eastern Labrador Sea. Associated with the decrease in transport over the Eirik Ridge section is a decrease in current speed; at the deepest stations the mean speed for height above bottom $h<300 \mathrm{~m}$ at the Irminger Sea stations is $0.158 \mathrm{~ms}^{-1}$, while over the Eirik Ridge section it is $0.124 \mathrm{~ms}^{-1}$. There is no increase in speed at those depths in the Labrador Sea $\left(0.129 \mathrm{~ms}^{-1}\right)$. Most of the decrease in volume transport from the Irminger Sea to the Eirik Ridge is seen in the density range of the NEADW (Figure 7). It is reasonable to expect some section-to-section differences during a survey spread over 4 weeks, but it is also possible that a significant reduction in the mean DWBC transport across the Ridge does actually occur, as is shown in Figure 6. If this is the case, it would run counter to the historical view that the entire DWBC simply follows the topography and directly enters the Labrador Sea, and would indicate a WBC less continuous than previously thought. To investigate the transport variations further we next examine the velocity and water mass structure along the apparent pathway of the DWBC.

The Irminger Sea section confirms the present knowledge about the DWBC at this location. The plume of cold, fresh DSOW hugs the sloping seafloor deeper than about 1500m (Figure 2), with the coldest and freshest core observed below about 2700m. Associated with the cold, fresh plume are increased velocities (Figure 5), though the highest velocities are found rather higher up the sloping sides of the basin than the property core $(2000-2700 \mathrm{~m})$. From the abyssal plain eastwards the velocities reverse direction, with the flow being northwards reflecting the cyclonic circulation within the Irminger Sea. The short Spur section which extends 
perpendicular to the Eirik Ridge section indicates that the same basic hydrographic and velocity structures persist along the southern flanks of the Ridge where the topography has similar slope and orientation as that of the Irminger Sea section (Figure 3). Figure 7 shows the absence of any mid-depth velocity minimum, and for density range $\sigma_{\theta}>27.80 \mathrm{~kg} \mathrm{~m}^{-3}$, the dominance of NEADW in the DWBC.

At the crest of the Eirik Ridge the structure of the bathymetry has changed significantly as follows; the slope of the sea floor is rather less steep below $1500 \mathrm{~m}$, and the orientation of the isobaths reverses, forcing the flow to turn a sharp corner. The properties of the DSOW $\left(\sigma_{\theta}>27.88 \mathrm{~kg} \mathrm{~m}^{-3}\right)$ look similar to those in the Irminger Sea, though the densest layers of the DSOW are absent over the Ridge. In the density range of the NEADW there are some clear differences, most strikingly that the most saline NEADW has disappeared. This can be seen in Figure 4 where the saline knee of the NEADW is eroded from the Irminger Sea (and Spur/Stub sections) to the Eirik Ridge section. In fact the properties of the NEADW at the Eirik Ridge section have moved towards a mixing line between the purest form of NEADW seen in the eastern Irminger Sea and the freshest DSOW (dotted black line in Figure 4). This may not be surprising given the turbulent nature of the flow which enhances diapycnal mixing (Lauderdale et al, 2008). Figure 7 (panels a and c) shows a concentration of the transport into the core of the DWBC, caused by a reduction in the lightest and densest layers, but no compensating increase in transport in the core. There are two possible explanations for these observations; firstly that some part of the DWBC (approximately 2- $3 \mathrm{~Sv}$ ) has separated from the main current before it reached the crest of the Eirik Ridge, and secondly that the observations are reflecting natural short-term fluctuations in the DWBC transport. 
In the Labrador Sea section there are further notable changes. The salinity maximum of the NEADW has been reduced further, and a different variety of DSOW is observed (colder, fresher and more dense). The most dramatic change is the great increase in volume transport evident in both the depth and density graphs in Figure 7. Figure 5 shows that while the deepest layer $(h<300 \mathrm{~m})$ of the DWBC shows no increase in speed, the shallower DWBC has higher cross-track velocities than either the Irminger Sea or the Eirik Ridge sections.

Since there is evidence of an intermediate depth recirculation cell in the Labrador Sea, it is possible that the surprisingly large transport measured in the DWBC in the eastern Labrador Sea has been enhanced by the addition of recirculating deep waters. The presence of colder, fresher, denser DSOW not seen in the other sections does support this view. However if this were the case, the transport estimate at that location of $19.7 \pm 3.9 \mathrm{~Sv}$ would be an overestimate of the net transport in the DWBC by as much as 9-10 Sv. It is already known that synoptic surveys in this location may be prone to large errors due to mesoscale activity as follows. In computing a mean velocity section across the Labrador Sea from a series of repeat hydrographic sections from the 1990s, Pickart and Spall (2007) observed the highest velocity errors (associated with the mean) in the deep western boundary current. They suggest the variability is associated with the formation of deep-reaching eddies spawned from the boundary current (e.g. Katsman et al, 2004) and the presence of bottom-trapped topographic Rossby waves (Pickart, 1995). We suggest that the large deep transport measured in the Labrador Sea section is in part due to recirculation of dense water, and in part a result of synoptic errors introduced by mesoscale activity.

c. Intermediate Depths 
The mean circulation of the LSW around Cape Farewell is described by Lavender et al (2005, see their Figure 13). Their mapped mean circulation from float trajectories showed two cyclonic recirculation cells either side of the Eirik Ridge, with net westward flow over the Ridge close to the continental slope, and net eastward flow at the southern end of the Ridge. This circulation scheme is replicated in the D298 data (Figure 6), with both the Irminger Sea and Labrador Sea sections partially traversing the two cyclonic cells, and the Eirik Ridge section sampling LSW flowing westwards in the northern part of the section, and flowing eastwards to the south. The transport values for LSW density range of $\sigma_{\theta}=27.70-27.80 \mathrm{~kg} \mathrm{~m}^{-3}$ (Table 1 and Figure 6) reflect that scheme, but do not resolve the net transports through the Irminger Sea and Labrador Sea because the CTD sections are not coastto-coast. The data can however provide an estimate of the strength of the recirculation cells; across the Irminger Sea section, the LSW at all stations in water < $3300 \mathrm{~m}$ deep flows southwards and transport a total of $-12.2 \pm 2.4 \mathrm{~Sv}$. At the south corner, the westward transport is reduced to $8.3 \pm 1.6 \mathrm{~Sv}$, implying approximately 4 Sv recirculates within the Irminger Sea. At the Labrador Sea section the northwest transport is increased to $20.0 \pm 4.0 \mathrm{~Sv}$ suggesting around $12 \mathrm{~Sv}$ recirculating in the interior. There is a net flow from the Labrador Sea into the Irminger Sea, though this survey does not allow us to quantify that.

\section{d. Shallow Western Boundary Current}

A detailed study of the shallow circulation during the D298 survey was given in Holliday et al (2007). The analysis showed that the EGC (red arrow in Figure 8) merged with the cold, fresh EGCC (blue arrow in Figure 8) to the south of Cape Farewell to form the West Greenland Current. The EGC and EGCC waters include 
cold, fresh polar water and warm, saline Atlantic water (often called the Irminger Current in this location), and together they formed $-14.7 \pm 1.0 \mathrm{~Sv}$ at the Irminger Sea section, $15.1 \mathrm{~Sv} \pm 1.0$ over the Eirik Ridge section, but only $11.7 \pm 1.0 \mathrm{~Sv}$ at the Labrador Sea section. The mismatch of transports between the Eirik Ridge and the Labrador Sea was approximately balanced by $5.1 \mathrm{~Sv}$ of EGC water that retroflected from the WBC at Eirik Ridge into the central Irminger Sea. The transports given in Holliday et al (2007) included only the EGC/EGCC water; when examining the upper waters for $\sigma_{\theta}<27.70 \mathrm{~kg} \mathrm{~m}^{-3}$ there is an additional water type, the Subarctic Surface Water (SASW). The cold, fresh, stratified SASW alters the total transport of waters lighter than $\sigma_{\theta}=27.70 \mathrm{~kg} \mathrm{~m}^{-3}$ (Table 1 and Figure 8), with interior cyclonic recirculation in the Labrador Sea and Irminger Sea (1-2 Sv), and additional southward flow over the deepest parts of the Eirik Ridge. The D298 Irminger Sea transport value for $\sigma_{\theta}<27.70 \mathrm{~kg} \mathrm{~m}^{-3}$ of $16.0 \pm 3.3 \mathrm{~Sv}$ southward is similar to other recent estimates (15.5 Sv in Lherminier et al (2007) and 13.6 Sv in Pickart et al (2005)).

\section{SUMMARY OF RESULTS}

The regional circulation scheme agrees with existing knowledge about the WBCs and intermediate circulation to the south of Greenland, and the D298 synoptic survey has shed new light on the complexity of the WBCs. The main findings are listed below and shown graphically in Figures 6 and 8. The polar-origin and NACorigin waters in the EGC merge with the very cold fresh EGCC to flow into the Labrador Sea as the West Greenland Current, with around a third of the transport leaving the boundary and retroflecting into the Irminger Sea. The intermediate waters have a net flow from the Labrador Sea to the Irminger Sea but are characterised by recirculating cells in the Irminger and Labrador basins. The DWBC decreases in 
volume at the south corner as some flow diverges from the main current. The remaining dense current follows the topography from the Irminger Sea into the Labrador Sea, where it is enhanced by recirculating water.

The major results from the analysis of D298 August/September 2005 survey are as follows:

* The WBC system transports $-40.5 \pm 8.1 \mathrm{~Sv}$ in the Irminger Sea, and $53.8 \pm$ 10.8 Sv in the Labrador Sea (surface to seafloor).

* The westward flow in the WBC system is reduced to $29.6 \pm 5.9 \mathrm{~Sv}$ at the south corner, over the Eirik Ridge.

* There is no mid-depth level of no motion in the WBC, but using a reference level in the mid-depth region of low vertical shear (1000-1400 dbar) indicates that baroclinic transport accounts for around half of the total transport.

* The transport observed in the DWBC $\left(\sigma_{\theta}>27.80 \mathrm{~kg} \mathrm{~m}^{-3}\right)$ is $-12.3 \pm 2.5 \mathrm{~Sv}$ across the Irminger Sea section, $8.7 \pm 1.7 \mathrm{~Sv}$ across the Eirik Ridge section and $19.7 \pm$ 3.9 Sv across the Labrador Sea section. Approximately $60-70 \%$ of the transport is in the shallower North East Atlantic Deep Water (NEADW).

* The maximum velocity core of the Denmark Strait Overflow Water (DSOW) is found at 2000-2700 dbar in the Irminger Sea, while the seawater property core (coldest, freshest DSOW) is found below $2700 \mathrm{dbar}$.

* The speed of the DSOW (at $300 \mathrm{~m}$ above the seafloor) decreases from 0.16 $\mathrm{ms}^{-1}$ in the southern Irminger Sea, to $0.12-0.13 \mathrm{~ms}^{-1}$ over the Eirik Ridge and in the southern Labrador Sea. 
* The significant decrease in the transport in the DWBC observed in the vicinity of the Eirik Ridge (approximately 30\%) was associated with a volumetric loss of the most saline classes of NEADW.

* The decrease in transport from the Irminger Sea to the Eirik Ridge implies that either some part of the DWBC leaves the boundary current before it enters the Labrador Sea, or else the semi-synoptic survey is affected by short time-scale fluctuations in DWBC transport.

* The significant increase in transport in the DWBC measured in the Labrador Sea was associated with the presence of recirculating deep waters (a colder, fresher, denser form of DSOW) and increased volume of the denser classes of NEADW. It is likely that deep mesoscale variability characteristic of this location has led to an overestimation of the DWBC transport and recirculation.

* The Labrador Sea Water observations agree with the scheme presented in Lavender et al (2005) with recirculating cells either side of the Eirik Ridge and net flow from the Labrador Sea into the Irminger Sea. The survey suggests that approximately $4 \mathrm{~Sv}$ recirculates within the Irminger Sea, and $12 \mathrm{~Sv}$ in the Labrador Sea.

* Around Cape Farewell the WBC is far from continuous; there are recirculations that enhance it, and divergent pathways that result in losses from it.

\section{DISCUSSION}

In the following paragraphs we discuss the implications of the new results in the context of existing knowledge and future analysis. 


\section{a. Interannual to decadal variability: the impact of methodology}

The transport estimates for the WBC system given here from a single survey in 2005, are slightly different to the small number of previous estimates of combined baroclinic and barotropic transport. An important question is whether the differences reflect some true variability, or whether they reflect variations in sampling techniques and analysis methods. At least some of the difference in transport estimates for the DWBC at Cape Farewell can be attributed to the methodology employed in each analysis. The division of the entire flow into layers can be subjective and varies between surveys. The choice of dividing parameter can significantly influence the resulting transport value; for example the CTD and current meter data that provided the widely cited DWBC transport of $-13.3 \mathrm{~Sv}$ south of Cape Farewell from Clarke (pers. comm) quoted in Dickson and Brown (1994), was given as -16.0 Sv in Clarke (1984) when calculated from the same data using a slightly different approach (though details of the methods were not given). A further example of this is given in Table 1 from D298. It is sometimes argued by authors that using the isopycnal $\sigma_{\theta}=$ $27.80 \mathrm{~kg} \mathrm{~m}^{-3}$ to define the upper limit of the DWBC is similar to using the $3^{\circ} \mathrm{C}$ isotherm. Bacon and Saunders (submitted) show from the combination of D298 CTD data and 12 months of current meter and temperature data, that there is only a small difference in the calculated mean transport over 12 months between using the $3^{\circ} \mathrm{C}$ isotherm $(7.1 \pm 0.8 \mathrm{~Sv})$ or the $27.80 \mathrm{~kg} \mathrm{~m}^{-3}$ isopycnal $(8.6 \pm 1.0 \mathrm{~Sv})$ as the upper limit for the DWBC. But the isopycnal definition leads to a $50 \%$ increase in the transport estimate from the synoptic D298 CTD/LADCP survey $\left(8.8 \mathrm{~Sv}\right.$ for $\theta<3.0^{\circ} \mathrm{C}, 12.3 \mathrm{~Sv}$ for $\sigma_{\theta}>27.80 \mathrm{~kg} \mathrm{~m}^{-3}$ ). The additional transport occurs because in this survey of the Irminger Sea the isopycnal is considerably shallower than the isotherm. Note that for the remaining sections shown in Figure 2, the isotherm is largely coincident with the 
isopycnal. In summary there is no obvious "correct" way to define the DWBC. However, given the fairly recent understanding that properties (temperature, salinity and possibly density) of the overflow water do change with time, we conclude that the DWBC definitions should be taken into account when comparing transport estimates from different data sets.

\section{b. Synoptic versus sustained measurements}

It has long been understood that synoptic surveys provide information that is likely to be biased by unknown variability on a range of time and space scales. When a one-time survey such as D298 is compared to sustained measurements which began at the same time and in the same location, it provides an opportunity to assess the representativeness of the synoptic survey. During D298 several current meter moorings were deployed in the DWBC along the Irminger Sea section. The initial results from the array are given in Bacon and Saunders (submitted to JPO). They show that the DWBC (defined as water cooler than $3^{\circ} \mathrm{C}$ ) transports an average of -7.1 $\pm 1.0 \mathrm{~Sv}$ over a 12 -month period. At first glance this seems significantly smaller than the $-12.3 \pm 2.5 \mathrm{~Sv}$ from the synoptic survey $\left(\sigma_{\theta}>27.80 \mathrm{~kg} \mathrm{~m}^{-3}\right)$, but as noted above, the definition of the DWBC is critical. The D298 survey gives a DWBC transport of $8.8 \pm 1.0 \mathrm{~Sv}$ for $\theta<3.0^{\circ} \mathrm{C}$, the number directly comparable to the current meter observations. Bacon and Saunders (submitted to JPO) show that there is significant short-term variability in the transport of the DWBC, and that over the 12 month period the transport for $\theta<3.0^{\circ} \mathrm{C}$ declined from a mean of $-8.4 \pm 1.9 \mathrm{~Sv}$ over the first 60 days of the time series, to $-5.1 \pm 1.3 \mathrm{~Sv}$ in the last 60 days (error bars are the standard deviation of 12-hour means). The $-8.4 \mathrm{~Sv}$ at the start of the current meter time series is very close to the $-8.8 \mathrm{~Sv}$ computed from the CTD/LADCP data, so we 
conclude that the synoptic survey is representative of the DWBC over that 2 month period.

c. Divergence of the deep western boundary current at Eirik Ridge

The decrease in transport within the DWBC between the Irminger Sea section and the Eirik Ridge is an interesting result which cannot be fully understood with the data presently available. In this section we propose and discuss a new hypothesis which could explain the results but which needs further testing. The hypothesis is as follows: in the vicinity of the Eirik Ridge the barotropic DWBC diverges over the sharply changing topography, with around half continuing into the Labrador Sea, and the remaining half flowing into the interior of the subpolar gyre. The null hypothesis is that the boundary current continues intact into the Labrador Sea, and that the observations are the effect of sub-sampling short-term variability and intense turbulence in the boundary current.

The water mass analysis provides evidence to support the new hypothesis; the loss of volume and transport of the most saline classes of NEADW in the short distance between the Stub/Spur sections and the Eirik Ridge section (Figure 4) cannot be easily explained as simply a result of mixing (albeit intense). Furthermore, earlier studies in the region have suggested from quite different sources there may be alternative routes for NEADW and DSOW to reach the DWBC at Flemish Cap, other than via the Labrador Sea. An extensive analysis of hydrographic and nutrient data by McCartney (1992) showed recirculating components of North Atlantic deep waters. The DWBC is notable for its minimum silicate concentration in the DSOW and maximum in the NEADW, and Figure 24 from that manuscript suggests that while the low silicate plume turns to the west in the region of the Eirik Ridge, some of 
the higher silicate plume turns southward. A more recent overview of observations in and around the Labrador Sea since 1996 (Stramma et al, 2004) notes that the sections at the Flemish Cap sample a version of NEADW (which they call Gibbs Fracture Zone Water, GFZW) that has higher salinity than the western boundary stations (in which the NEADW has been mixed with and modified by the fresher waters of the interior of the Labrador Sea). The authors note that this implies "some westward movement of GFZW outside of the boundary current system" and suggest that there may be a direct route from the Charlie Gibbs Fracture Zone. We cannot test that hypothesis, but it is equally possible that the more saline NEADW at Flemish Cap has come from the Eirik Ridge.

Finally, we note that Cape Farewell is likely not the only location in the North Atlantic sub-polar gyre where the DWBC is (at least partly) discontinuous. Bower et al (2009) clearly demonstrate DWBC discontinuity off the Grand Banks, Newfoundland.

\section{d. The relationship between the DWBC, bathymetry and sedimentation}

Associated with the Eirik Ridge is a thick Holocene sediment drift constructed through deposition by the deep currents, with the thickest deposits lying on the Labrador Sea side of the ridge crest (Hunter et al, 2007) . Most of the sediment load is presently carried in the DSOW, but it is thought that the NEADW is also a source of material at times (Hunter et al, 2007). Thick deposits of sediments at the Eirik Ridge may make it a suitable site for investigating the decadal to millennial scale variability of the DWBC which is known to vary on geological time scales (Bianchi and McCave, 1999). Relating the present day currents in this region with the surface sediment distribution may be key to interpreting the historical data. However this 
analysis shows that establishing the net transport in the DWBC at Cape Farewell is complicated by the presence of recirculation features, additions to, and losses from the main current feature. The sediment drift lies within the Labrador Sea recirculation feature west of the ridge, so sedimentation rate may well be most strongly coupled with the strength of that feature, and not necessarily with the strength of the net DWBC. The association between variations in the net DWBC strength and the recirculation cells in this region may be best resolved with a modelling study.

\section{ACKNOWLEDGEMENTS}

This study was funded as part of the NERC Rapid Climate Change Programme. The bathymetry image in Figure 8 was provided by Gavin Elliot, NOCS. 


\section{REFERENCES}

Bacon, S., 1998: Evidence for decadal variability in the outflow from the Nordic Seas to the deep Atlantic Ocean. Nature, 394, 871-874.

Bacon, S., 1997: Circulation and fluxes in the North Atlantic between Greenland and Ireland. Journal of Physical Oceanography, 27, 1420-1435.

Bacon, S., 2006: RRS Discovery Cruise 298, 23 Aug - 25 Sep 2005. Cape Farewell and Eirik Ridge (CFER-1). National Oceanography Centre, Southampton, Cruise Report No. 10, 113 pp.

Bacon, S., P. Myers, B. Rudels and D. Sutherland, 2008: Accessing the Inaccessible: buoyancy-driven coastal currents on the shelves of Greenland and eastern Canada. Chapter 28, pp. 701-720 in, Arctic-Subarctic Ocean Fluxes:

Defining the role of the Northern Seas in Climate, eds. R. R. Dickson, J. Meincke and P. Rhines. Springer-Verlag, Berlin, 738 pp.

Bacon, S., G. Reverdin, I. G. Rigor, and H. M. Snaith, 2002: A freshwater jet on the east Greenland shelf. Journal of Geophysical Research, 107, 10.1029/2001JC000935.

Bacon, S. and P. M. Saunders, 2008: The Deep Western Boundary Current at Cape Farewell: Results from a moored current meter array. submitted to Journal of Physical Oceanography.

Bersch, M., 1995: On the circulation of the northeastern North Atlantic, DeepSea Research I, 42, 1583-1607.

Bianchi, G.C. and I.N. Mc Cave, 1999: Holocene periodicity in North Atlantic 
climate and deep ocean flow south of Iceland. Nature, 397, 515-517

Bower, A. S., M. S. Lozier, S. F. Gary and C. W. Boning, 2009: Interior pathways of the North Atlantic Meridional Overturning. Nature, in press.

Chough, S.K. and R. Hess, 1985: Contourites from Eirik Ridge, south of Greenland. Sed Geol. 41, 185-199.

Clarke, R. A., 1984: Transport through the Cape Farewell - Flemish Cap section. Rapp. P.-v. Reun. Cons. int. Explor. Mer, 185, 120-130.

Clarke, R. A. and J. C. Gascard, 1983: The formation of Labrador Sea Water 1. Large-scale processes. Journal of Physical Oceanography, 13, 1764-1778.

Cuny, J., Rhines, P.B., Niiler, P. P., and Bacon, S., 2002: Labrador Sea Boundary Currents and the Fate of Irminger Sea Water. Journal of Physical Oceanography, 32, 627-647.

Dickson, R. R. and J. Brown, 1994: The production of North Atlantic Deep Water: sources, rates and pathways. Journal of Geophysical Research, 99, 1231912341.

Dickson, R., S. Dye, S. Jónsson, Köhl, A. Macrander, M. Marnela, J. Meincke, S. Olsen, B. Rudels, H. Valdimarsson, and G. Voet, "The overflow flux west of Iceland: Variability, Origins and Forcing", In: Dickson, R.R., Meincke, J. and Rhines, P. (eds.) Arctic-Subarctic Ocean Fluxes. Berlin, Springer, 569-612.

Egbert, G. D. and S. Y. Erofeeva, 2002: Efficient inverse modelling of barotropic ocean tides. Journal of Atmospheric and Oceanic Technology, 19, 183 204. 
Egbert, G. D., A. Bennett, and M. Foreman, 1994: TOPEX/Poseidon tides estimated using a global inverse model. Journal of Geophysical Research, 99, 2482124852.

Fischer, J., F. A. Schott, M. Dengler, 2004: Boundary circulation at the exit of the Labrador Sea. Journal of Physical Oceanography, 34, 1548-1570.

Hakkinen, S. and P. B. Rhines, 2004: Decline of subpolar North Atlantic circulation during the 1990s. Science, 304, 555-559.

Holliday, N. P., A. Meyer, S. Bacon, S. Alderson, and B. A. de Cuevas, 2007: The retroflection of part of the East Greenland Current at Cape Farewell. Geophysical Research Letters, 34, L07609.

Hunter, S., A. Wilkinson, E. Louarn, I.N. McCave, E. Rohling, D.A.V.Stow, S. Bacon, 2007: Deep western boundary current dynamics and associated sedimentation on the Eirik Drift, Southern Greenland Margin. Deep Sea Research I, 54, 2036-2066.

Katsman, C.A., M.A. Spall, and R.S. Pickart, 2004: Boundary current eddies and their role in the restratification of the Labrador Sea. Journal of Physical Oceanography, 34, 1967-1983.

Keike, D. and M. Rhein, 2006: Variability of the overflow water transport in the western subpolar North Atlantic, 1950-97. Journal of Physical Oceanography, 36, $435-456$.

Lauderdale, J. M., S. Bacon, A. C. Naveira Garabato, and N. P. Holliday, 2008: Intensified turbulent mixing in the boundary current system of southern 
Greenland. Geophysical Research Letters, 35, L04611.

Lavender, K. L., W. B. Owens, and R. E. Davis, 2005: The mid-depth circulation of the subpolar North Atlantic Ocean as measured by subsurface floats. Deep-Sea Research Part I, 52, 767-785.

Lherminier, P., H. Mercier, C. Gourcuff, M. Alvarez, S. Bacon, and C. Kermabon, 2007: Transports across the 2002 Greenland-Portugal Ovide section and comparison with 1997. Journal of Geophysical Research, 112, C07003.

McCartney, M. S., 1992: Recirculating components to the deep boundary current of the northern North Atlantic. Progress in Oceanography, 29, 283-383.

McDonagh, E. L., H.L. Bryden, B.A. King, and R.J. Sanders, 2008: The circulation of the Indian Ocean at $32^{\circ} \mathrm{S}$. Progress in Oceanography, 79, (1), 20-36.

Pickart, R.S. 1995: Gulf Stream-generated topographic Rossby Waves. Journal of Physical Oceanography, 25, 574-586.

Pickart, R.S. and M.A. Spall, 2007: Impact of Labrador Sea convection on the North Atlantic meridional overturning circulation. Journal of Physical Oceanography, 37, 2207-2227.

Pickart, R. S., D. J. Torres, and P. S. Fratantoni, 2005: The East Greenland Spill Jet. Journal of Physical Oceanography, 35, 1037-1053.

Reynaud, T.H., A.J. Weaver, and R.J. Greatbatch, 1995: Summer mean circulation of the northwestern Atlantic Ocean. Journal of Geophysical Research, 100, p779-816. 
Saunders, P. M., 1994: The flux of overflow water through the Charlie-Gibbs Fracture Zone. Journal of Geophysical Research, 99, 12343-12355.

Saunders, P. M., 2001: The dense northern overflows. Ocean circulation and climate; observing and modelling the global ocean., G. Siedler, J. Church, and W. J. Gould, Eds., Academic Press, 715.

Schott, F.A., R. Zantopp, L. Stramma, M. Dengler, J. Fischer, M. Wibaux, 2004: Circulation and deep water export at the western exit of the subpolar North Atlantic. Journal of Physical Oceanography, 34, 817-843.

Stramma, L., D. Keike, M. Rhein, F. Schott, I. Yashayaev, and K. P. Koltermann, 2004: Deep water changes at the western boundary of the subpolar North Atlantic during 1996 to 2001. Deep-Sea Research I, 51, 1033-1056.

Sutherland D.A., and R.A. Pickart, 2008: The East Greenland Coastal Current: Structure, variability and forcing. Progress in Oceanography, 78, 58-77.

van Aken, H. M. and C. J. de Boer, 1995: On the synoptic hydrography of intermediate and deep water masses in the Iceland Basin. Deep-Sea Research, 42, 165-189.

Visbeck, M., 2002: Deep velocity profiling using Lowered Acoustic Doppler Current Profilers: bottom track and inverse solutions. Journal of Atmospheric and Oceanic Technology, 19, 794-807.

Yashayaev, I., M. Bersch, and H. van Aken, 2007a: Spreading of the Labrador Sea Water to the Irminger and Iceland basins. Geophysical Research Letters, 34, L10602. 
Yashayaev, I., H. van Aken, N. P. Holliday, and M. Bersch, 2007b:

Transformation of the Labrador sea water in the subpolar North Atlantic. Geophysical Research Letters, 34, L22605. 


\section{FIGURES}

Figure 1. Map of the Discovery 298 survey in August-September 2005 around Cape Farewell, Greenland. Crosses indicate the location of CTD/LADCP stations.

Figure 2. Salinity (top) and potential temperature (bottom, ${ }^{\circ} \mathrm{C}$ ) from D298, August-September 2005. Left panels are from the Labrador Sea section, right panels from the Irminger Basin (see Figure 1). Tick marks and numbers at the top indicate CTD station positions. The thick lines denote the isopycnals referred to in the text $\left(\sigma_{\theta}\right.$ $=27.70,27.77,27.80$ and $27.88 \mathrm{~kg} \mathrm{~m}^{-3}$ ).

Figure 3. Salinity (top) and potential temperature (bottom, ${ }^{\circ} \mathrm{C}$ ) from D298, August-September 2005. Left panels are from the Eirik Ridge section, centre panels from the Spur section and right panels from the Stub section (see Figure 1). Tick marks and numbers at the top indicate CTD station positions. The thick lines denote the isopycnals referred to in the text $\left(\sigma_{\theta}=27.70,27.77,27.80\right.$ and $\left.27.88 \mathrm{~kg} \mathrm{~m}^{-3}\right)$.

Figure 4. Potential Temperature-Salinity diagrams from the D298 sections. The light grey data given in the Irminger Sea figure are stations in the eastern Irminger Sea. The black dotted line denotes a mixing line between the North East Atlantic Deep Water in the vicinity of the Mid Atlantic Ridge and the Denmark Strait Overflow Water. Also shown are selected isopycnals $\left(\sigma_{\theta}=27.70,27.77,27.80\right.$ and $\left.27.88 \mathrm{~kg} \mathrm{~m}^{-3}\right)$, isotherms $\left(\theta=2^{\circ}\right.$ and $\left.3^{\circ} \mathrm{C}\right)$ and isohalines $(\mathrm{S}=34.88$ and 34.93$)$.

Figure 5. Cross-track geostrophic velocity $\left(\mathrm{cm} \mathrm{s}^{-1}\right)$ referenced to ADCP data (see Section 2) and cumulative transport (Sv) computed from zero at the Greenland coast (the crest of the Eirik Ridge in the case of Spur and Stub sections). Positive 
values are northwards. Positive velocity contours are denoted by dashed lines, negative contours by solid lines.

Figure 6. Schematic illustrations of Western Boundary Current transport (Sv) in various density classes. White numbers in black ellipses show the total volume transport measured by the D298 Aug-Sept 2005 CTD/LADCP survey, while arrows show the direction of flow. Shaded regions show the horizontal extent of individual density class; where no shaded arrows are shown, that density class covers the entire region. Black numbers in open ellipses indicate estimated (i.e. not observed) transport values. (a) Surface to sea floor transport: North of the dashed line all stations show net westward flow, while to the south of the dotted line, all stations show net eastward flow. (b) Upper ocean, including EGCC and EGC (shaded arrows) and SASW (dotted arrows). (c) LSW. (d) NEADW. (e) DSOW. (f) DWBC including NEADW and DSOW.

Figure 7. Transport (Sv) across the 3 main sections shown as a function of pressure and density. Panels (a) Irminger Sea, (b) Labrador Sea, and (c) Eirik Ridge, include those stations pairs within the WBC. Panel (d) shows Eirik Ridge station pairs outside of the WBC (note the different horizontal axis range). Positive transport is northwards;).

Figure 8. a) The bathymetry of Cape Farewell depicted as a three-dimensional image (courtesy of Gavin Elliot, NOCS). The view is approximately northwards towards Cape Farewell so that both basins are visible. The vertical exaggeration is 100:1. b) The D298 potential temperature sections (as shown in Figures 2 and 3) superimposed on the bathymetry. c) Schematic of the mean flow field derived from the D298 August-September CTD/LADCP survey (from Figure 7). The arrows are 
coloured so as to correspond approximately with the temperature sections in panel (b) as follows: light blue is the East Greenland Coastal Current, red is the East Greenland/West Greenland Current including polar and sub-polar water, pink is Labrador Sea Water, pale blue is North East Atlantic Deep Water, and dark blue is Denmark Strait Overflow Water (together forming the Deep Western Boundary Current). 


\section{TABLES}

Table 1. Total synoptic transports (Sv) in the western boundary current system around Cape Farewell in Aug-Sept 2005. Irminger Sea values are for stations inshore of the $3300 \mathrm{~m}$ isobath to include only the WBC. Positive is northward. Eirik Ridge values are separated into north- or westwards (positive, within WBC) and south-eastwards (negative, recirculations and divergent flow).

\begin{tabular}{|l|lll|}
\hline & Irminger Sea & Eirik Ridge & Labrador Sea \\
\hline Surface to Seafloor Total & $\mathbf{- 4 0 . 5} \pm \mathbf{8 . 1}$ & $\mathbf{2 9 . 6} \pm \mathbf{5 . 9}(\mathbf{- 4 3 . 4} \pm \mathbf{8 . 7})$ & $\mathbf{5 3 . 8} \pm \mathbf{1 0 . 8}$ \\
Upper Ocean $\sigma_{\theta}<27.70 \mathrm{~kg} \mathrm{~m}^{-3}$ & $-16.0 \pm 3.2$ & $15.6 \pm 3.1(-10.3 \pm 2.1)$ & $14.1 \pm 2.8$ \\
LSW $\sigma_{\theta}=27.70-27.80 \mathrm{~kg} \mathrm{~m}^{-3}$ & $-12.2 \pm 2.4$ & $8.3 \pm 1.6(-31.4 \pm 6.3)$ & $20.0 \pm 4.0$ \\
NEADW $\sigma_{\theta}=27.80-27.88 \mathrm{~kg} \mathrm{~m}^{-3}$ & $-8.7 \pm 1.7$ & $7.4 \pm 1.5(-6.4 \pm 1.2)$ & $12.0 \pm 2.4$ \\
DSOW $\sigma_{\theta}>27.88 \mathrm{~kg} \mathrm{~m}^{-3}$ & $-3.6 \pm 0.7$ & $2.2 \pm 0.4(-0.5 \pm 0.1)$ & $7.7 \pm 1.5$ \\
DWBC $\theta<3.0^{\circ} \mathrm{C}$ & $-8.8 \pm 1.8$ & $6.4 \pm 1.3(-9.0 \pm 1.8)$ & $15.6 \pm 3.1$ \\
DWBC $\sigma_{\theta}>27.80 \mathrm{~kg} \mathrm{~m}^{-3}$ & $-12.3 \pm 2.5$ & $8.7 \pm 1.7(-6.8 \pm 1.4)$ & $19.7 \pm 3.9$ \\
\hline
\end{tabular}


Table 2. Baroclinic transport in the deep western boundary current in Aug-Sept 2005.

Values are for stations inshore of the $3300 \mathrm{~m}$ isobath i.e. within the WBC; positive is northward.

\begin{tabular}{|c|c|c|c|c|c|c|}
\hline & \multicolumn{3}{|c|}{ Irminger Sea } & \multicolumn{3}{|c|}{ Labrador Sea } \\
\hline & $\begin{array}{l}\text { Baroclinic } \\
\text { Trans. ref } \\
1000 \text { dbar }\end{array}$ & $\begin{array}{l}\text { Baroclinic } \\
\text { Trans. ref } \\
1400 \text { dbar }\end{array}$ & $\begin{array}{l}\text { Total } \\
\text { Trans (ref } \\
\text { ADCP). }\end{array}$ & $\begin{array}{l}\text { Baroclinic } \\
\text { Trans. ref } \\
1000 \mathrm{dbar}\end{array}$ & $\begin{array}{l}\text { Baroclinic } \\
\text { Trans. ref } \\
1400 \text { dbar }\end{array}$ & $\begin{array}{l}\text { Total } \\
\text { Trans. (ref } \\
\text { ADCP) }\end{array}$ \\
\hline $\begin{array}{l}N E A D W \\
\sigma_{\theta}=27.80-27.88 \\
\mathrm{~kg} \mathrm{~m}^{-3}\end{array}$ & -4.1 & -3.6 & -8.7 & 4.7 & 4.1 & 12.0 \\
\hline $\begin{array}{l}\text { DSOW } \\
\sigma_{\theta}>27.88 \mathrm{~kg} \mathrm{~m}^{-3}\end{array}$ & -2.8 & -2.6 & -3.6 & 4.8 & 4.4 & 7.7 \\
\hline $\begin{array}{l}\text { Total DWBC } \\
\sigma_{\theta}>27.80 \mathrm{~kg} \mathrm{~m}^{-3}\end{array}$ & -6.9 & -6.2 & -12.3 & 9.5 & 8.5 & 19.7 \\
\hline
\end{tabular}




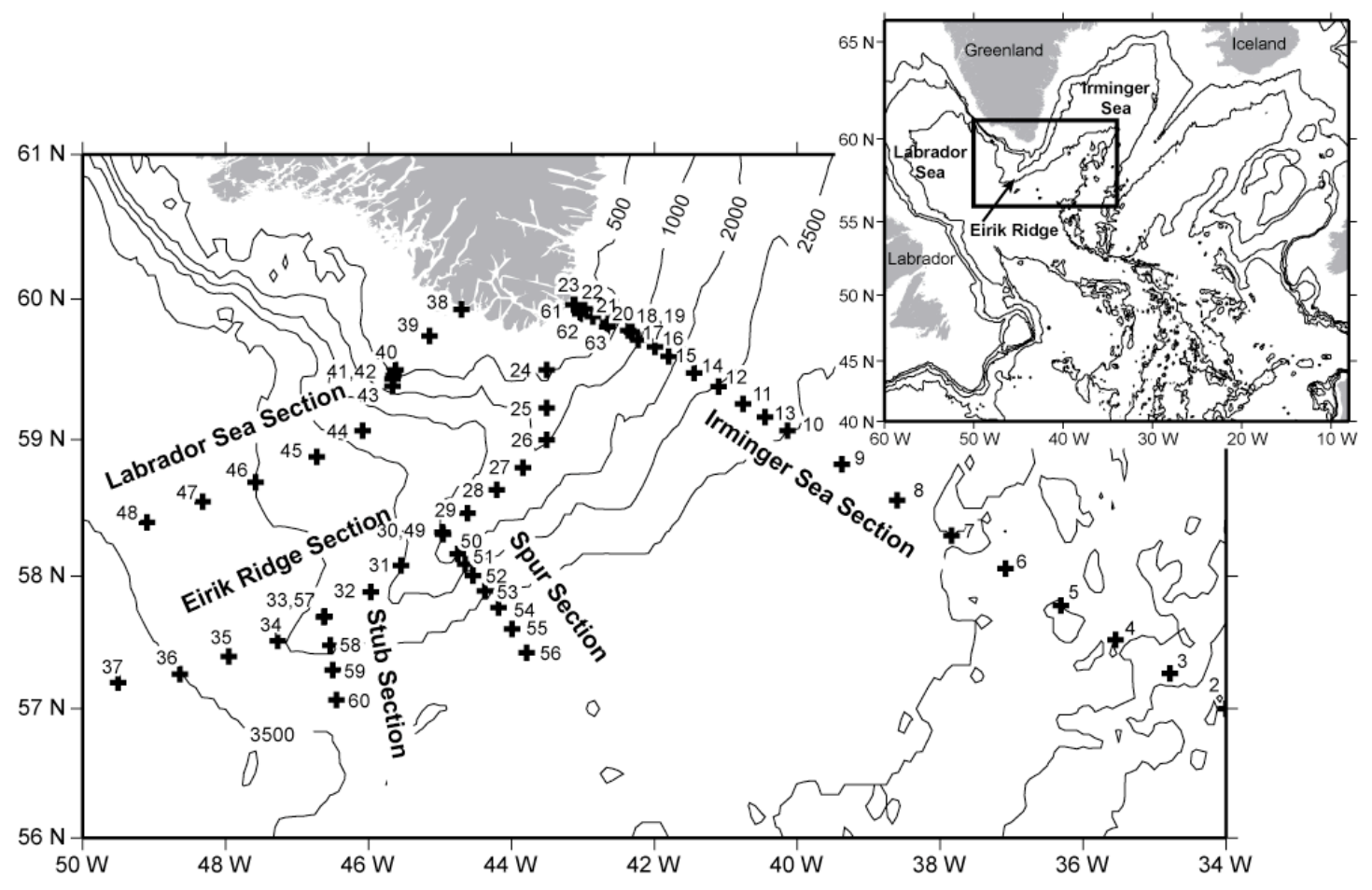

1. Map of the Discovery 298 survey in August-September 2005 around Cape Farewell, Greenland. Crosses indicate the location of CTD/LADCP stations. 

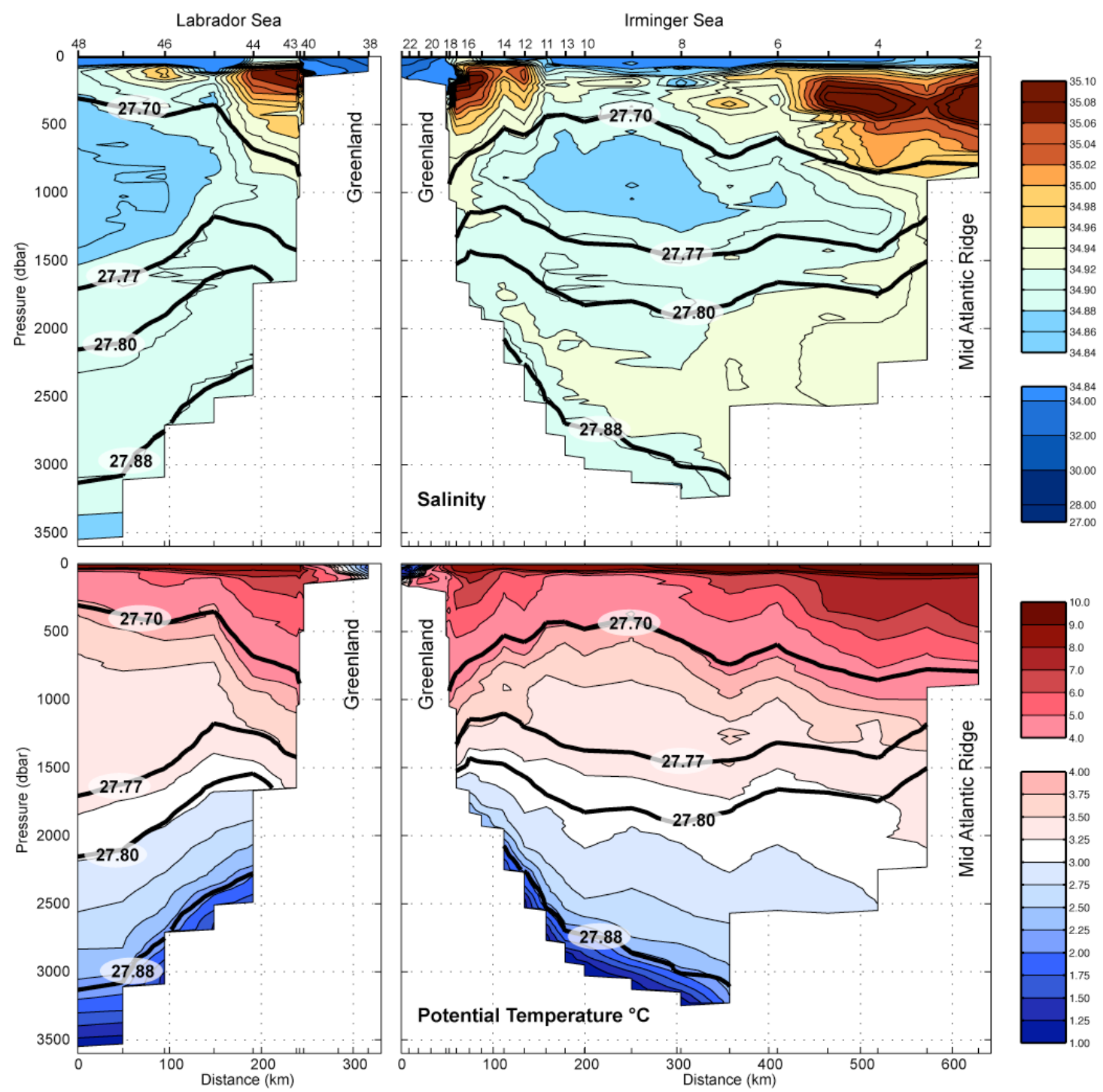

Figure 2. Salinity (top) and potential temperature (bottom, ${ }^{\circ} \mathrm{C}$ ) from D298, AugustSeptember 2005. Left panels are from the Labrador Sea section, right panels from the Irminger Basin (see Figure 1). Tick marks and numbers at the top indicate CTD station positions. The thick lines denote the isopycnals referred to in the text $\left(\sigma_{\theta}=\right.$ $27.70,27.77,27.80$ and $27.88 \mathrm{~kg} \mathrm{~m}^{-3}$ ). 


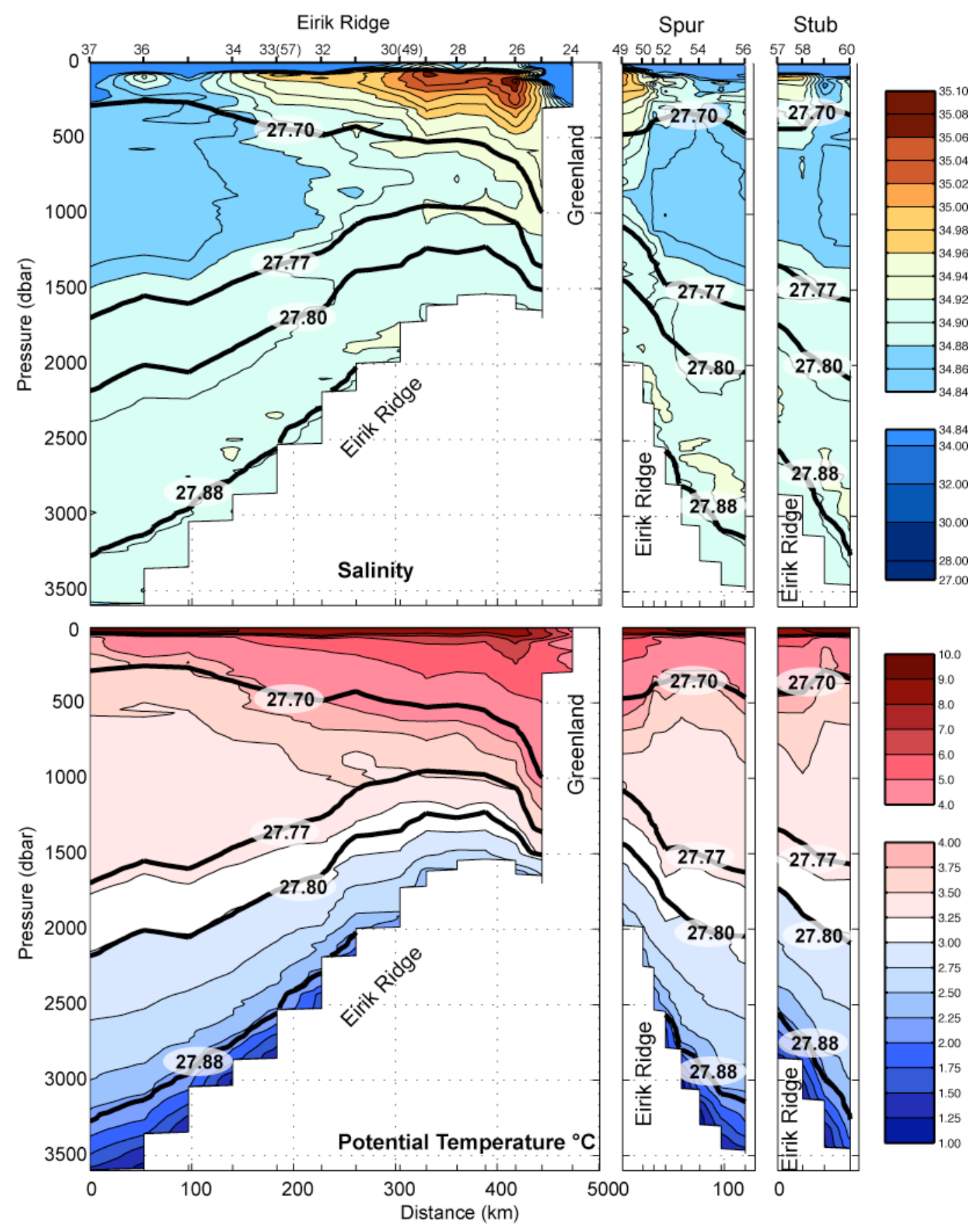

Figure 3. Salinity (top) and potential temperature (bottom, ${ }^{\circ} \mathrm{C}$ ) from D298, AugustSeptember 2005. Left panels are from the Eirik Ridge section, centre panels from the Spur section and right panels from the Stub section (see Figure 1). Tick marks and numbers on top horizontal axis indicate CTD station positions. The thick lines denote the isopycnals referred to in the text $\left(\sigma_{\theta}=27.70,27.77,27.80\right.$ and $\left.27.88 \mathrm{~kg} \mathrm{~m}^{-3}\right)$. 

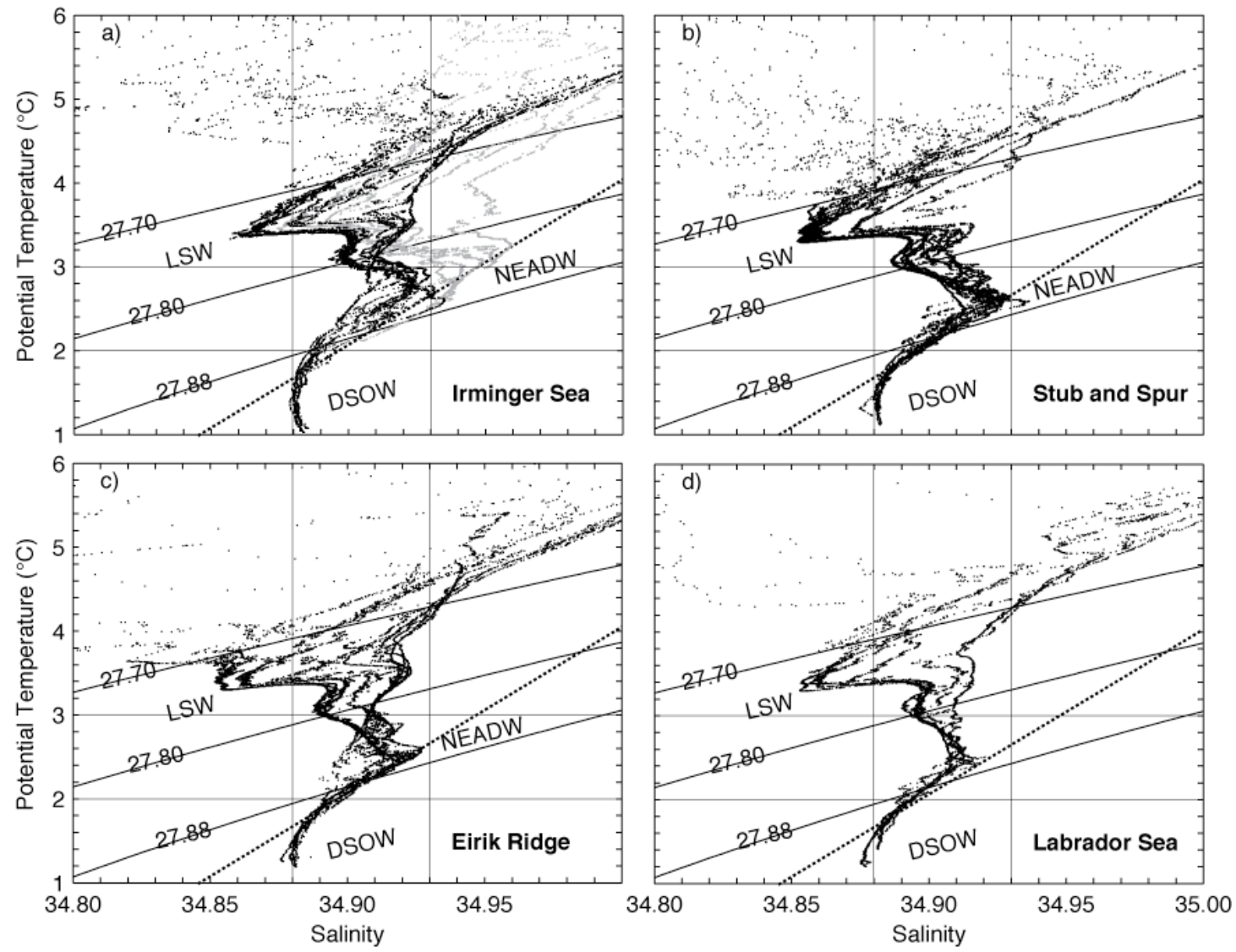

Figure 4. Potential Temperature-Salinity diagrams from the D298 sections. The light grey data given in the Irminger Sea figure are stations in the eastern Irminger Sea. The black dotted line denotes a mixing line between the North East Atlantic Deep Water in the vicinity of the Mid Atlantic Ridge and the Denmark Strait Overflow Water. Also shown are selected isopycnals $\left(\sigma_{\theta}=27.70,27.77,27.80\right.$ and $27.88 \mathrm{~kg} \mathrm{~m}^{-}$ $\left.{ }^{3}\right)$, isotherms $\left(\mathrm{t}=2^{\circ}\right.$ and $\left.3^{\circ} \mathrm{C}\right)$ and isohalines $(\mathrm{S}=34.88$ and 34.93$)$. 

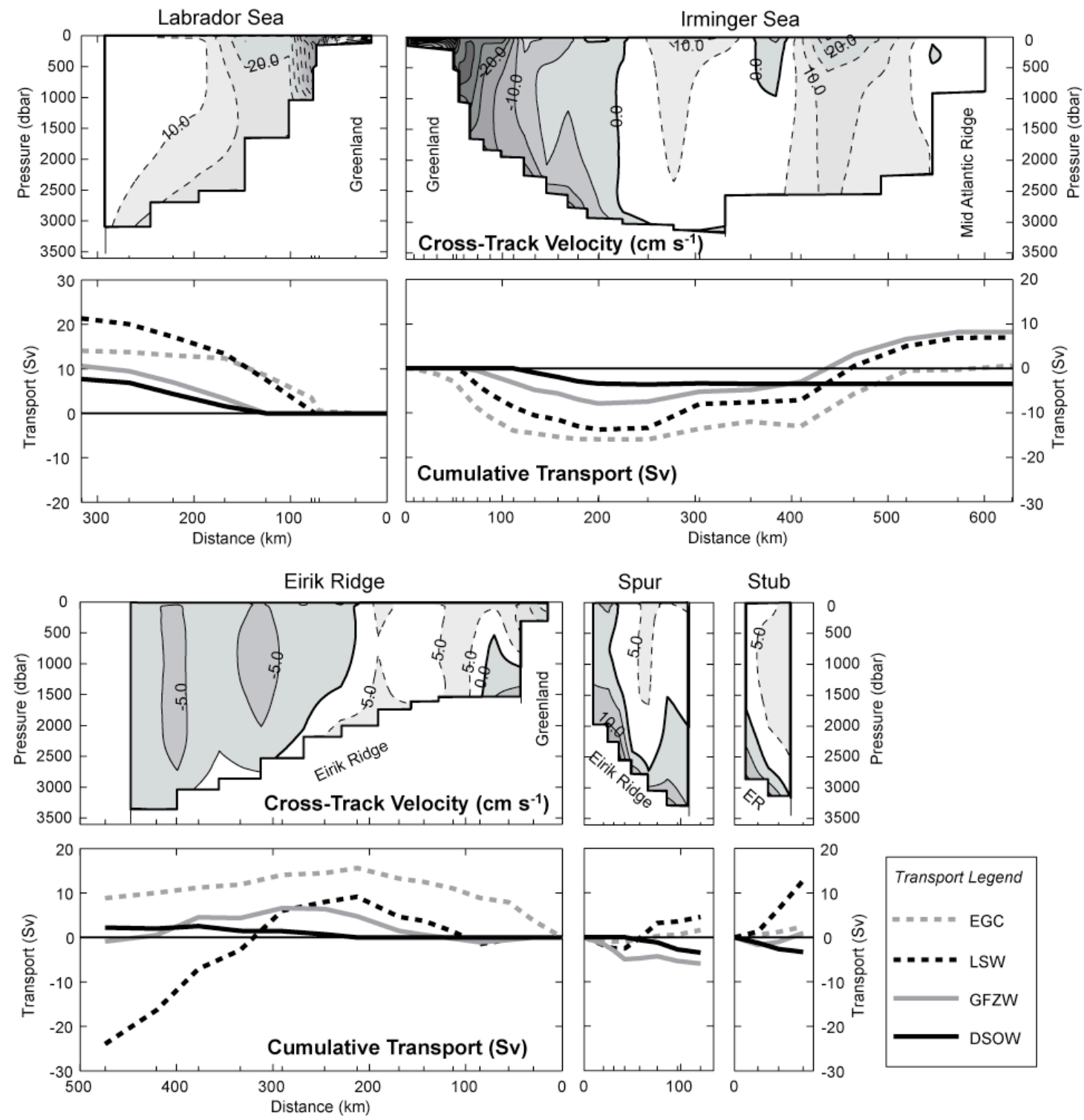

Figure 5. Cross-track geostrophic velocity $\left(\mathrm{cm} \mathrm{s}^{-1}\right)$ referenced to ADCP data (see Section 2) and cumulative transport (Sv) computed from zero at the Greenland coast (the crest of the Eirik Ridge in the case of Spur and Stub sections). Positive values are northwards. Positive velocity contours are denoted by dashed lines, negative contours by solid lines. 

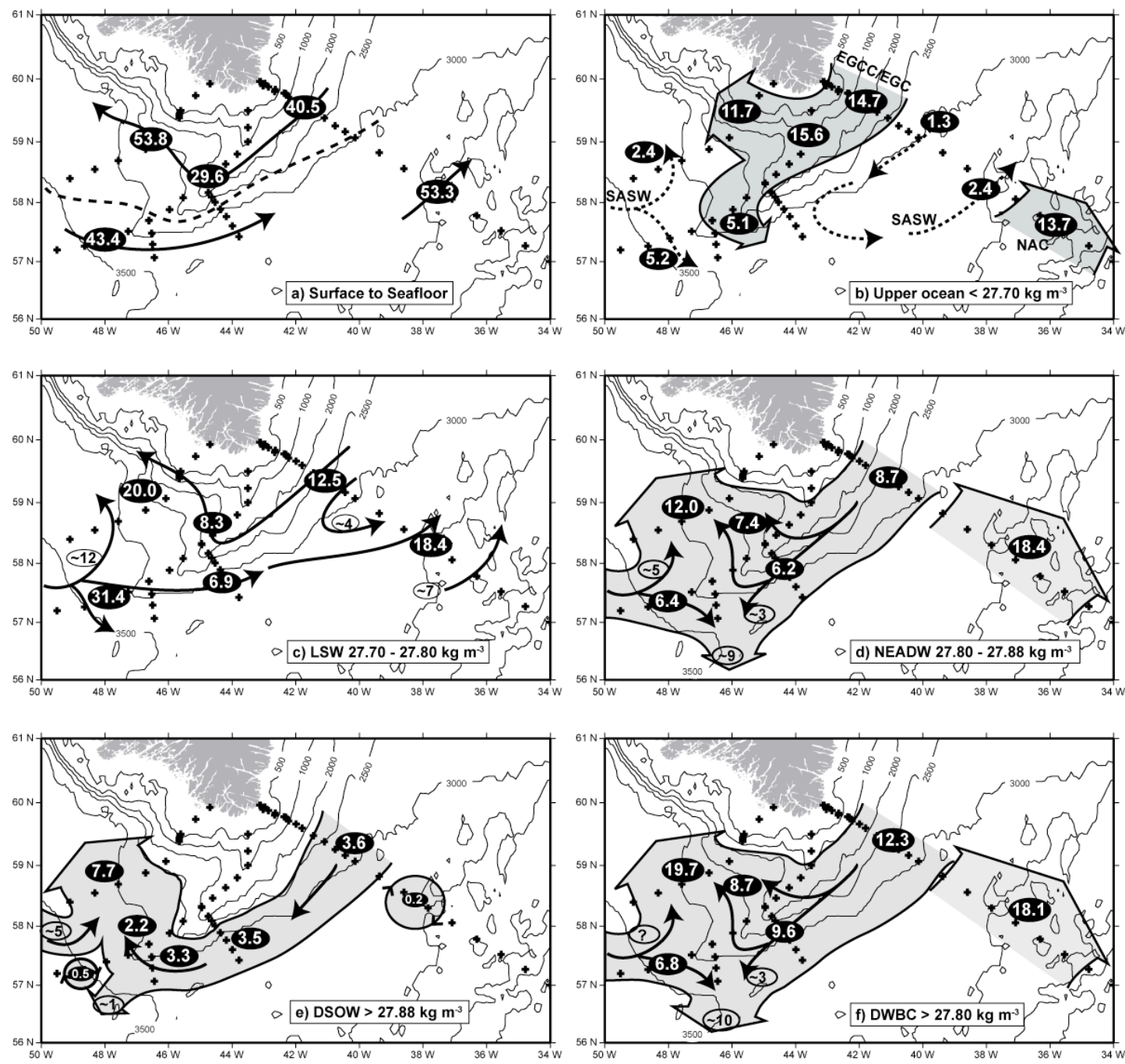

Figure 6. Schematic illustrations of Western Boundary Current transport (Sv) in various density classes. White numbers in black ellipses show the total volume transport measured by the D298 Aug-Sept 2005 CTD/LADCP survey, while arrows show the direction of flow. Shaded regions show the horizontal extent of individual density class; in panels (a) and (c) where no shaded arrows are shown, that density class covers the entire region. Black numbers in open ellipses indicate estimated (i.e. not observed) transport values. (a) Surface to sea floor transport; north of the dashed line all stations show net westward flow, while to the south of the dotted line, all stations show net eastward flow. (b) Upper ocean, including EGCC and EGC (shaded arrows) and SASW (dotted arrows). (c) LSW. (d) NEADW. (e) DSOW. (f) DWBC including NEADW and DSOW. 

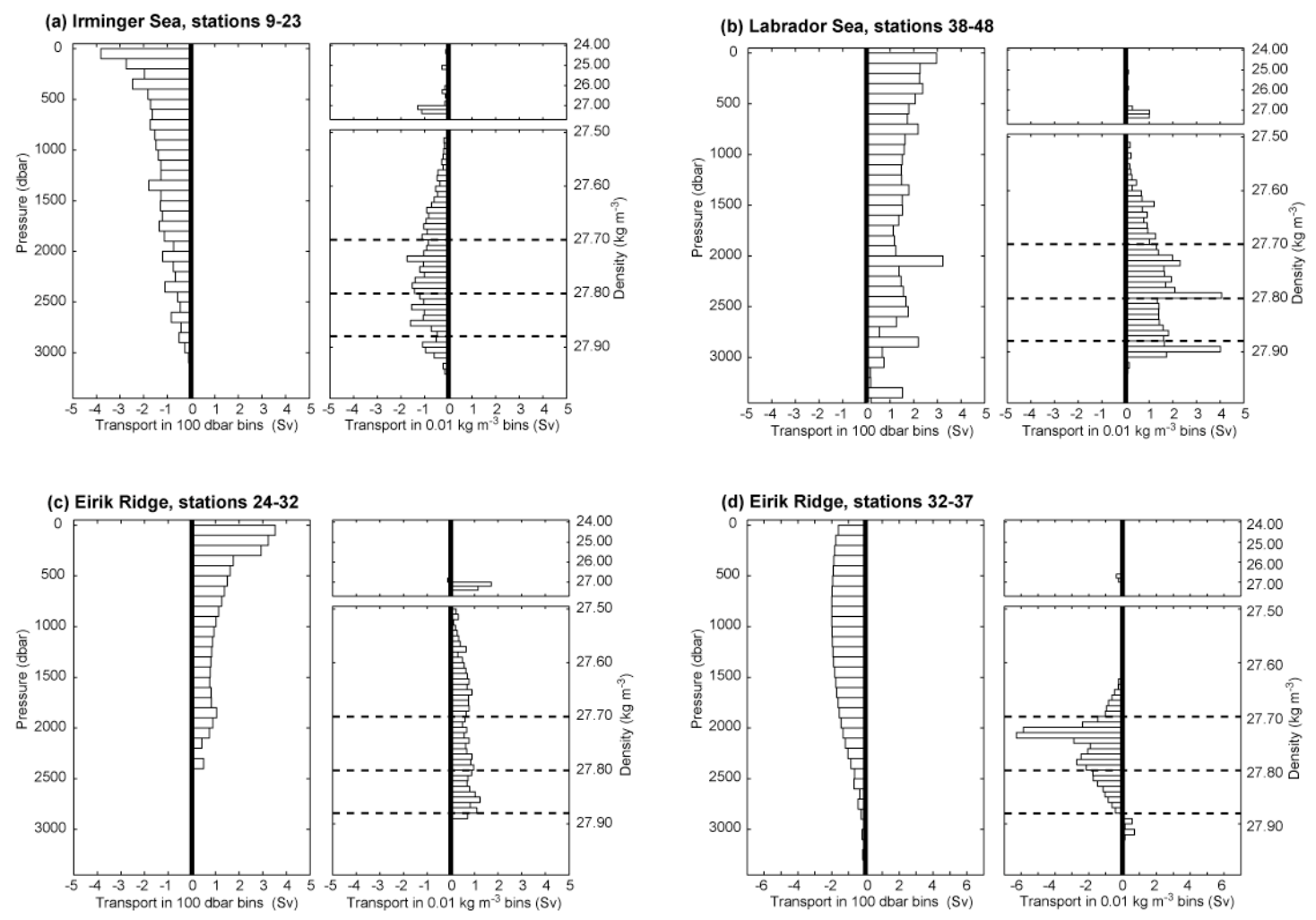

Figure 7. Transport (Sv) across the 3 main sections shown as a function of pressure and density. Panels (a) Irminger Sea, (b) Labrador Sea, and (c) Eirik Ridge, include those stations pairs within the WBC. Panel (d) shows Eirik Ridge station pairs outside of the WBC (note the different horizontal axis range). Positive transport is northwards;). 

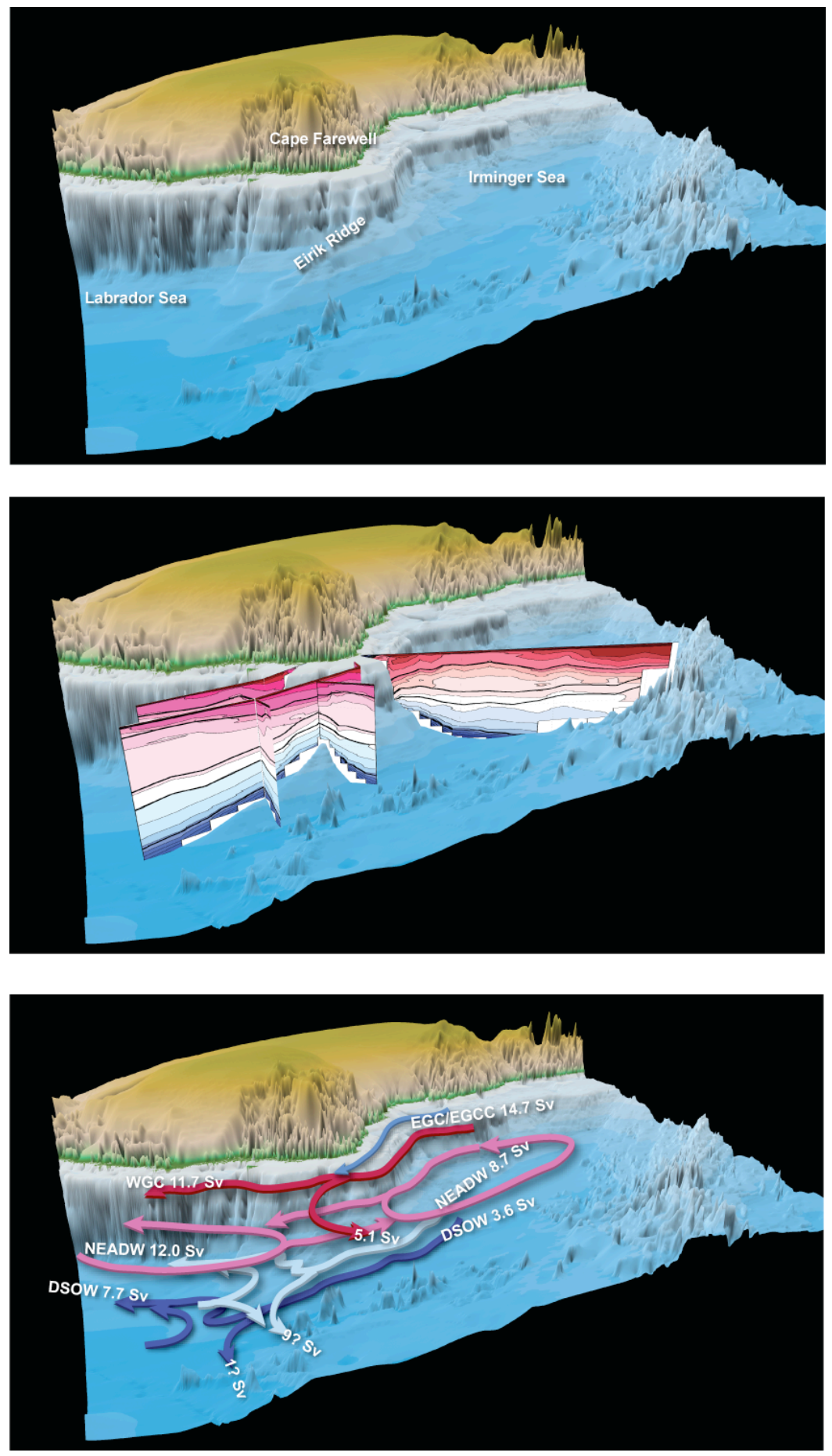

Figure 8. a) The bathymetry of Cape Farewell depicted as a three-dimensional image (courtesy of Gavin Elliot, NOCS). The view is approximately northwards towards Cape Farewell so that both basins are visible. The vertical exaggeration is 100:1. b) The D298 potential temperature sections (as shown in Figures 2 and 3) superimposed on the bathymetry. c) Schematic of the mean flow field derived from the D298 August-September CTD/LADCP survey (from Figure 7). The arrows are coloured so as to correspond approximately with the temperature sections in panel (b) as follows: light blue is the East Greenland Coastal Current, red is the East Greenland/West Greenland Current including polar and sub-polar water, pink is Labrador Sea Water, pale blue is North East Atlantic Deep Water, and dark blue is Denmark Strait Overflow Water (together forming the Deep Western Boundary Current). 